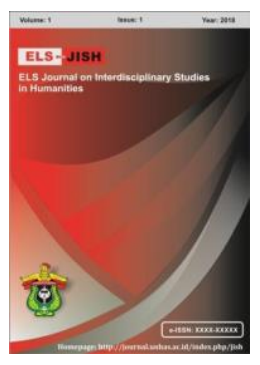

ELS-JISH

ELS Journal on Interdisciplinary Studies on Humanities

Volume 3 Issue 4, 2020

ISSN (print) : 2621-0843

ISSN (online) : 2621-0835

Homepage : http://journal.unhas.ac.id/index.php/jish

\title{
The Representation of Social Class in the Illustration of Sketches by Boz by Dickens
}

\author{
Nurul Imansari ${ }^{1}$ \\ nurul.imansari@unsulbar.ac.id
}

\begin{abstract}
The study object in this research is the representation of social class in the illustration of Sketches by Boz by Charles Dickens (1895). Social class is one of the most prominent themes raised by Charles Dickens in his work to satirize the condition of Victorian England as a form of empathy towards the lower class people. Dickens tries to portray that phenomenon into a series of story and illustration of people's everyday life in his work 'Sketches by Boz'. However, this social phenomenon is always depicted and discussed mostly in term of the narration form. On the contrary, illustration is often being ignored. The aim of this study is to bring together the importance of illustration in its relationship to the text. The method used in this study was a descriptive qualitative. It will examine how social class is portrayed in the illustration of Dickens' Sketches by Boz by focusing particularly on the variety of techniques used by the illustrators in producing the illustrations. The result shows that both narration and illustration highlights the social class reality in the Victorian era. The narration and the illustration cannot be separated in Charles Dickens' Sketches by Boz since it is created to be a description of people's everyday life in Victorian London.
\end{abstract}

Keywords: Charles Dickens, Illustration, Narration, Social Class

How to cite: Imansari, N. (2020). The Representation of Social Class in the Illustration of Sketches by Boz by Dickens. ELS-Journal on Interdisciplinary Studies in Humanities, 3(4), 506517. DOI: https://doi.org/10.34050/elsjish.v3i4.11914

\section{Introduction}

Social Class is one of the running themes in Charles Dickens's Sketches by Boz (1895) and its illustration. This theme is one of the most prominent themes raised by Dickens in his work to satirize the condition of Victorian London at the time. Sketches by Boz itself is Dickens' first published work in the nineteenth-century era as a portrait of people's daily life by presenting London's best and worst side such as the streets, shops, and the omnibuses. In his work, Dickens reveals London as a dark place which full of miserable things like slums, diseases, poverty, and crime. Generally, the writer in the nineteenthcentury era tends to raise theme of social class through the issue of morality as a form of empathy towards the lower class people. Dickens were collaborated with some great illustrators to produce his literary works which he write based on his observation of daily life in London in the Victorian era. In this period,

${ }^{1}$ Universitas Sulawesi Barat, Indonesia 
England has experienced the new industrial revolution era. This era creates many significant changes.

England was become one of the most important countries in Europe because of its good economic condition. Many great discoveries bring sophisticated life in British life, such as the new-found technology which made life so much easier than before. Machinery also changes the previous manual process. Later on, the massive change in this industrial era affects the social structure in society (Patten, 2012). The existing industrial revolution creates the social status gap in the nineteenth century of England. This social gap was created based on many factors such as power, authority, properties, job, education, living condition, and culture (Indrasari, Rahman, \& Abbas, 2020). The bourgeoisie community often treats the lower class people badly. They do not care about the labors health condition and paid them with low wages. The lower classes who do not own properties have no chance to change their position in the society. They do not have an opportunity to improve their living condition to be better. This phenomenon happen because they do not have any rights in politic. To enter the politic life, people need to get the proper education which only provided for the upper-class people at the moment. The poverty becomes a fate for the lower class people which remain unchangeable. In collaboration with some famous illustrators, Dickens tries to portray that phenomenon into a series of story and illustration of people's everyday life in his work 'Sketches by Boz'. However, this social phenomenon is always depicted and discussed mostly in term of the narration form and illustration often being ignored. The relationship of the language and image in a Victorian literary text has not been examined deeply. Whereas the collaboration of Dickens and his illustrators is really important for the reader because those illustrations can give the reader a depiction of an image based on the text (Cordery, 2005). Moreover, illustration always being considered as the second place to language and also always seen as the inferior form of art. Therefore, in this writing, the researcher wants to bring together the importance of illustration in its relationship to the text and how social class phenomenon can be captured into illustration form by the illustrator as well as in writing form. Thus, the researcher will examine how social class is portrayed in the illustration of Dickens' Sketches by Boz 1895 by focusing particularly on the variety of techniques used by the illustrators in producing the illustrations. Firstly, the researcher will explain argument about the relationship between the narration and the illustration in Sketches by Boz then identify the elements which represent the social status in the illustration and how do people from different class are differentiated. Also, the history of illustration and the changing technology of illustration will be considered to depict the representation of social class in Dickens' Sketches by Boz narration.

\section{Method}

The study takes Charles Dickens' Sketches by Boz (1895) as the primary texts and identifies the problem evoked in the novel. The method used in this study was a descriptive qualitative. By using Weitzman theory about the illustration and narration, the study examine how social class is portrayed in the illustration of Dickens' Sketches by Boz by focusing particularly on the variety of 
techniques used by the illustrators in producing the illustrations. Weitzman argues that the illustration is controlled by the content of the text and the illustration bound strongly to the text to explain the story within the narration. Firstly, the researcher will explain argument about the relationship between the narration and the illustration in Sketches by Boz then identify the elements which represent the social status in the illustration and how do people from different class are differentiated. Also, the history of illustration and the changing technology of illustration will be considered to depict the representation of social class in Dickens' Sketches by Boz narration. The secondary data will be reviewed through the library research method using a range of information sources such as the books, journals, articles relevant to the analysis, and internet search engines.

\section{Results}

The illustration is one of the most significant parts of Dickens' work. In the nineteenth century, Dickens initially was below the illustration's popularity. He was hired to write for the very famous illustration at the time by working in collaboration with some illustrators. One of the most popular illustrators in the nineteenth century England is George Cruikshank. He is a very well-establish artist which gain huge popularity in Victorian era because of his satirical and grotesque illustration style. However, later Dickens becomes very popular by his writing gradually and then the role of illustration becomes less. Over the time, Dickens who was very young become more popular than Cruikshank (Daniels, 1988). The price of literary works become more affordable for lower class people and increases the number of the reader. More people were learning to read and found that language was better and more sophisticated than images. Dickens work is regarded as the classic literary works which have bring a huge impact in raising the social consciousness of Victorian society (Hodnett, 1982).

The Victorian England period is marked by the industrial revolution which brings many significant changes in British everyday life at that period. As a historian Walter Houghton mentioned in 1858 that Sir Henry Holland referred this era as an age of transition (Samples, 2013). The sophistication of technology as the result of industrialization brings the way of life a lot easier. Manual process replaced by the machinery make the production become faster. However, although it brings many positive effects in everyday life, the revolution also has the negative impact for the people at that time. There is a common perception that the sophisticated industrial revolution can form the rigid social structure among people. The gap between the upper class and the urban poor society become bigger because of the living condition at that time. The bourgeoisie have strong power and authority over the lower class people while the poor people have no choice but survive in poverty.

All those social phenomena are depicted nicely by Dickens in his first work Sketches by Boz which tells clearly about the social phenomena in the everyday life of London. The reality of social class which exists in nineteenth century everyday life can be reflected simply through the media of narration or illustration. In this case, Dickens as one of the most popular writer in Victorian era tries to capture this phenomenon in his narration. His first work in literature called 'Sketches by Boz' is a serialization of the everyday life of London as a 
reflection of reality in nineteenth century London. The social elements described in Dicken's Sketches by Boz play a strong and important role in the illustration which captured some particular moment in the narrative. In Sketches by Boz, Dickens pictures his observation on many places in London in the nineteenthcentury era along with the living conditions, culture, and morals. In his work, Dickens shows his empathy towards the lower class community suffers by the sovereign power of the bourgeoisie. He observed the miserable daily life of London and creates his works to satirize this condition. In the nineteenth century, social status was regarded as a crucial factor of moral character. The higher a person moral character, the higher his/her social status at the time. The purpose of Charles Dickens' work is to portray the disruption in industrial revolution era such as the degradation of moral.

There are some opinions about the interplay of literary text and the illustration. Some of the scholars question whether the media of narration or illustration can be trusted and reflected the social reality in Victorian England at the time. Weitzman argues that the illustration is controlled by the content of the text and the illustration bound strongly to the text to explain the story within the narration (Weitzmann, 1970). So, the relationship of the text and illustration can be a complement each other as a unity. The visual image can complete the story in the narration which cannot be expressed by the words. By seeing an image, the reader can visualize what the text has explained. Both illustration and the text are like a mirror. Through this mirror, the reader can see the reality. As well as Walter Crane points out that the reader's mind need a media to relieve stress which is encouraged when they read a narration text. In the process of reading the narration, the reader can be helped by the existence of the illustration which depicts the moment expressed by the text. The images can simplify the depiction in the text. Therefore, the relationship explained here is a kind of complement each other. However, there are some contradictory critics about the relationship that the text and illustration cannot be seen as a unity because they tend to depict opposite meaning. Marsh and White have to make the point that the text and the illustration cannot be interpreted in the same way as augmentation. One of them must be more demanding over another (Emily E. Marsh, 2003). Both text and illustration might be reflecting the same thing about reality. However, the reader can make different interpretation and opinion about the meaning. The reader should not put their trust with the illustration which accompanies a narrative text. Each illustrator definitely has their own style and thought to satirise or depict the cultural value of a community and social life. When the reader finished read the novel, they will create their own visualization about the reality depicted in both text and image. For example, the reality about social class in Victorian England explained in the narration is very bad. However, after the reader sees the illustration of the text they might get the different sense of it. The reader can make the interpretation that the reality depicted in the narration is not really in a serious condition as it generated by the illustration. The true reality can be interpreted in a contradictory way. So the reader would have different perception in reading the text and illustration whether the visual image follows the content of the image or it against the text. 
Forster in his book said that illustration is a work that always being underestimated by most of the people. According to Forster, he claims that illustration is an artwork which always being underestimated because it is personal and often obstructed because of the imperfection of used technique. Illustration always is categorized as something confusing between art and a non-art work (Forster, 1872). The image often is considered as an independent single subject apart from a literary text. He assumes that illustration is an important part of the nineteenth-century history, so it must be interpreted separately in a different way from the text. Sometimes, the illustrations released in Victorian era reflect the satire of Victorian society and contains more judgemental issue about the characters in the text and it can be contradicted with the representation in the original text. The illustration and the text cannot simply be separated each other because both of them have a very close relationship. The illustration is a visualized image from the literary text and vice versa, a narration within the text is a detail of a particular moment captured in illustration form. The experience of the reader when they read the literary narration will create the visualization of the symbols appeared in the text. Here Dickens tries to interest his reader to be actively participates in the process of analyzing and interpreting his narration by specifying more details to produce his literary work. Apart from this, the reader can rely on the illustration of Dickens' narrative because Dickens had described his original intention to the illustrators at the time. The images which have been chosen by Dickens to be illustrated also already been approved when the illustrations were finished their drawing.

Cohen in her book stated that Dickens often make the specification of the characters as well as their pose, move, action, expression, costume, and setting, for example, he even specified the detail of the colour, although the illustration was usually drawn in black and white version. In the same way, Dickens supplied his protagonist characters with his own ability to transfer his observation and experiences into the visual image by giving the impressive details of to the illustration (Cohen, 1980). The researcher would say that Dickens really pay attention to the details of the illustration and also to every aspect of his work. Cruikshank as his illustrator also transferred his concern and empathy as well as Dickens towards the social phenomenon of lower class people in London. However, there are many critics towards Cruikshank in term of his fidelity to Dickens' work, especially in the depiction of woman and children's character in Dickens text. The depiction of those innocent characters in the text seems to be old and ugly in appearance if the reader compared to the depiction in the narration. It might be related to the fact that Cruikshank as the so-called 'Hogarth's heir' because those characters did not really prominent in Hogarth's illustration description. Those characters are not reflected in Hogarth's illustration description. In understanding the narration, we need to think about the tone of the narrative text by investigating and exploring the sense of the mood and atmosphere of the contents of the text. Dickens might be want to expresses the sense of suffering, depressed and sorrowful feeling of the lower class in London his narration. The mood from the characters and settings also have to be considered in this case in order to create the atmosphere as well as the original intention of the writer or what the writer want 
to expresses. This kind of atmosphere can be produced by recording the expression and physical appearance from the characters within the narration. Maintaining the resemblance of the character in the reality depicted in narration can be helped by the description through the illustration. In the illustration, there is a need to recognize and choose particular objects and elements such as the physical features of the characters, the costumes, and the setting. The setting of the action in the text is required to be considered in the illustration to emphasize the atmosphere of the reality. Therefore, this atmosphere can be perceived by the reader to create the sense of reality. One of the most important aspect in drawing those objects and elements is their nature in the content of the narration, and the relationship to each other. We need to think and focus on actual representations of the reality and how the lines represent them into visualized form. The emphasis in the illustration is really important by giving the effect to particular lines and shapes in the content. The use of the illustration technique is a vital part to be considered.

Victorian era is one of the golden eras of illustration work where the printing media were exploded at that Industrialization period. The new found technology in Victorian era gives a huge contribution of the printed paper to the broad public reader. The illustration in the nineteenth century show some significance changes along with the history of its development. It creates many improvements from the earlier graphic art of the nineteenth-century era. Illustration in the early period is quite funny and humorous in style. While in the middle period, the style is more poetic and describes a more emotional feeling. The illustrators in this period tend to produce their works based on their experience and observation in daily life. In the nineteenth century era, the illustrations are influenced by the industrial techniques of engraving such as the use of wood. The style of illustration emphasis on interior, building, gesture, facial type, and clothes which represent the factual events which happened in that period of the reflection of human life. Those aspects also can be seen as the embodiment of social class. In the nineteenth century, England has experienced the great changes include the new technology of machinery. The industry of newspaper raises a significant popularity and produces a huge number of high-quality illustrations. The technique of illustration had been developed to printing technology. At the early period of the century, steelengraving was a major technique used in the illustration. (Browning, 2013).

This technique later on replaced by wood-engraving which used hardwood block. Then, the technique improved from the wood-engraving to a photomechanical technique which transfers the illustration into the printing plates by using the photographic tools. During the middle nineteenth century period, the technique of lithography was very common until the end of the period. Later on, it was replaced by technique of photo engraving. During the nineteenth century period, there is a changing technology of illustration. The improvement of illustration technique enables several types of illustration to develop.

In Sketches by Boz, the existence of social class reality in Victorian England is really clearly depicted. In this essay the researcher will choose some of the illustration sample from Sketches by Boz to identify the elements which 
created the sense and atmosphere of the social class difference. The set illustrated in the images are depicted into three categories in accordance to the social class in the nineteenth Century period. The first is the setting of the workhouse or which belong to the lower middle class people. The second is the setting of the slums and criminal place which full of crime and nasty people such as the pickpockets and the murderer. The third is the place of the Victorian middle class which belongs to the upper class people.

Dickens was released Sketches by Boz monthly which were usually etched on the steel plates and printed using special paper and then put in the bound version. In his working relationship with the illustrators, Dickens provides the artists with the overview of the text monthly so that the illustrators can start to produce their drawing before he writes his work. George Cruikshank is one of the greatest artists which famous of his social satirical illustration. His characterization in literary works depicts the exaggeration of features characteristic. Cruikshank's illustration is quite a cartoonist and photographic. The idea of realism is not really clear and even it does not show the idea of beautiful.

In identifying the social class issue in Dickens's Sketches by Boz, we need to have a look at the illustration image first. In the illustration of Seven Dials, the place is depicted as a notorious slum district. In Dickens's narrative, George Cruikshank sometimes shifted from one caricature mode to the other in illustrating the characters and the setting. In chapter five of Sketches by Boz, in 'Seven Dials' Dickens demonstrate the scene of two woman having a verbal fight as depicted in the conversation.

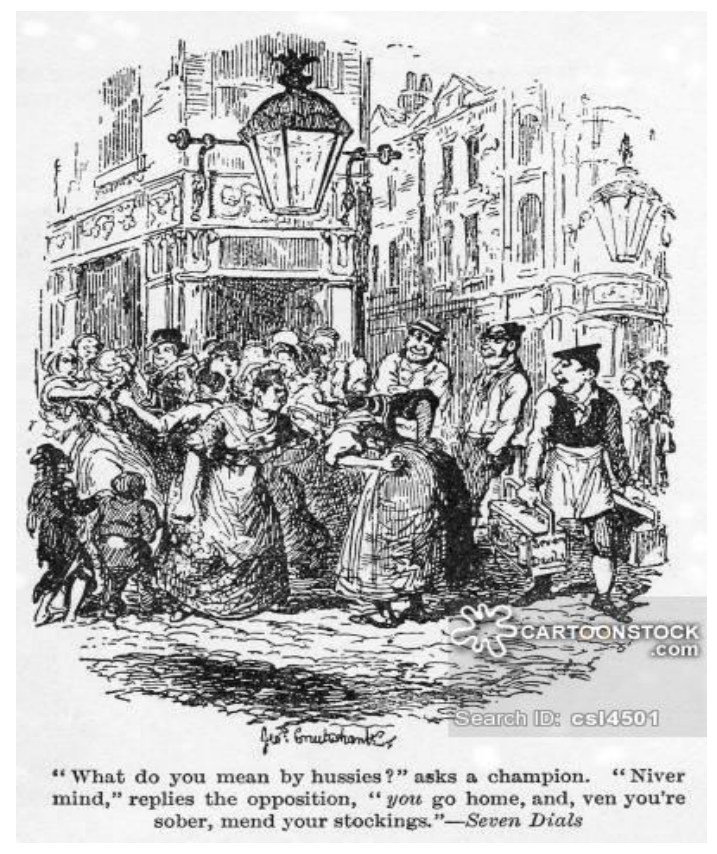

Figure 1. G Cruikshank "Seven Dials"

"What do you mean by hussies?' interrupts a champion of the other party, who has evinced a strong inclination throughout to get up a branch fight on her own account ('Hooroar,' ejaculates a pot-boy in parenthesis, 'put the kye-bosk on 
her, Mary!'), 'What do you mean by hussies?' reiterates the champion (Dickens, 1895).

Here, the narration demonstrates the scenes in the street where there are two women in the middle of crowd argue each other. In the illustration there is an image present the crowd situation and there are so many people surrounding two lower class women which seems having a verbal fight each other. The impression of the low social status can be seen in the construction of the streets which looks more bleaks and darker compare to the other scene. Moreover we can see the women are from lower social status by looking at their expression. Their gaze and large mouth when they are shouting shows a really weird expression while they are having fight. Also the gesture by putting two hands behind on the wrist in front of the public and the other group of woman who are involved in another fight can describe enough of their social status as a lower class people. It is very common for people in lower class to have fight in front of the public because are less educated. The upper class people in Victorian era are really careful in maintaining their attitude in front of the people.

The illustration visualized the image of the woman character and their emotion which embodying the situation in the nineteenth century London. Here, the style of Cruikshank illustration is quite close to caricature. Caricature itself is the special technique of capturing the specific traits, moral, and physical. It is also can be seen as the representation of individual personality depicted by those features. The manipulation representation of the characters reverses by both the exaggeration in the style of illustration and also the neglected elements which will compromise the focus of the image to be narrowed down. It needs to distort the balance of the components which maintain individual personality. Therefore by simplifying the identity of the characters will lead to reduce the effect of grotesque style as well as reduce the idealization.

The other illustration from Sketches by Boz narrative that is picked as an example to show the social class in the illustration is in the chapter nine of the book, called 'London recreations'. In the narrative, there is a description from Dickens about the situation.

"Some of the finery of these people provokes a smile, but they are all clean, and happy, and disposed to be good-natured and sociable. Those two motherly-looking women in the smart pelisses, who are chatting so confidentially, inserting a 'ma'am' at every fourth word, scraped an acquaintance about a quarter of an hour ago: it originated in admiration of the little boy who belongs to one of them-that diminutive specimen of mortality in the three-cornered pink satin hat with black feathers. The two men in the blue coats and drab trousers, who are walking up and down, smoking their pipes, are their husbands. The party at the opposite box is a pretty fair specimen of the generality of the visitors. These are the father and mother, and old grandmother: a young man and woman, and an individual addressed by the euphonious title of 'Uncle Bill,' who is evidently the wit of the party" (Dickens, 1895). 


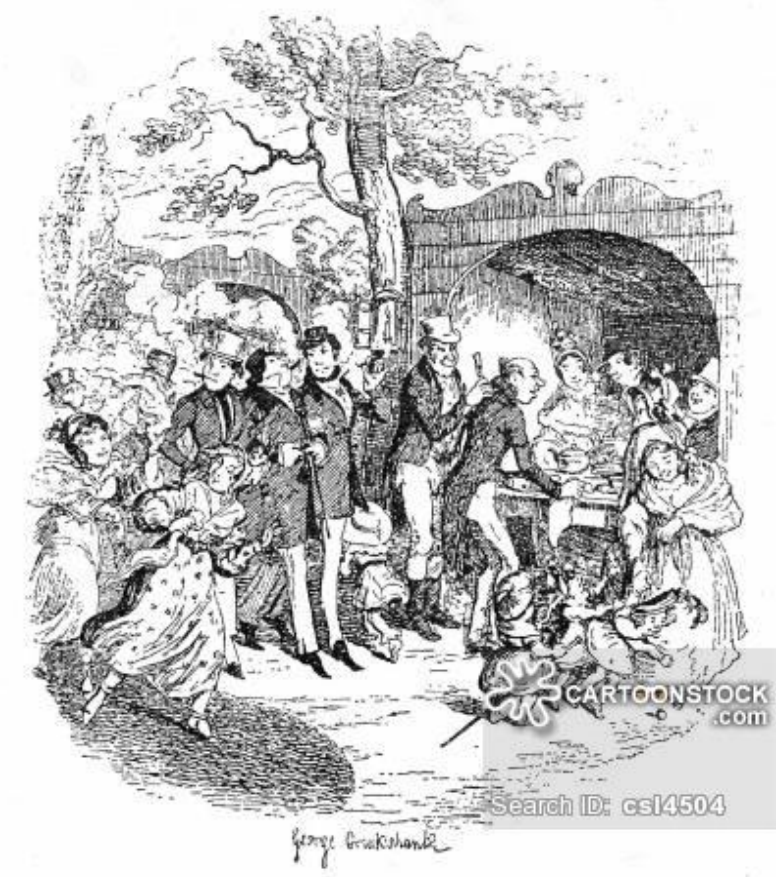

Uncle Bill is wafering a paper "pigtail" on the waiter's collar, and the old grandmother is in ecstasies,-London Recreations

Figure 2 G. Cruikshank, "The Tea gardens"

Here the illustration depicts the image of an upper class people in Victorian era, walking through the tea garden, having a relaxing cup of tea and cake, gathering with their family and relatives to spend their afternoon. We can see through the image that there are a group of aristocrats enjoy their spare time with family. The happiness is expressed by the gesture of raised hands, lovely looks, people's eye are opened wide and the figures of the children seem impatient for waiting their afternoon tea. From their physical features which tend to have a fit body posture. They are dressed in a really nice outfit with the nerdy suits and pretty dress which clearly represents the characters from the upper class people. The colour tone of the illustration also looks bright to reflect the emotional feeling of happiness. From the illustration we can see that the social class is clearly depicted in the images.

The other illustration is 'Public dinner' in chapter eighteen in the narrative. There is a scene in the narrative of Sketches by Boz expresses the physical features of the character:

"He, and the celebrated fireman's dog, were observed to be remarkably active at the conflagration of the two Houses of Parliament-they both ran up and down, and in and out, getting under people's feet, and into everybody's way, fully impressed with the belief that they were doing a great deal of good, and barking tremendously. The dog went quietly back to his kennel with the engine, but the gentleman kept up such an incessant noise for some weeks after the occurrence, that he became a positive nuisance. As no more parliamentary fires have occurred, however, and as he has consequently had 
no more opportunities of writing to the newspapers to relate how, by way of preserving pictures he cut them out of their frames, and performed other great national services, he has gradually relapsed into his old state of calmness." (Dickens, 1895)

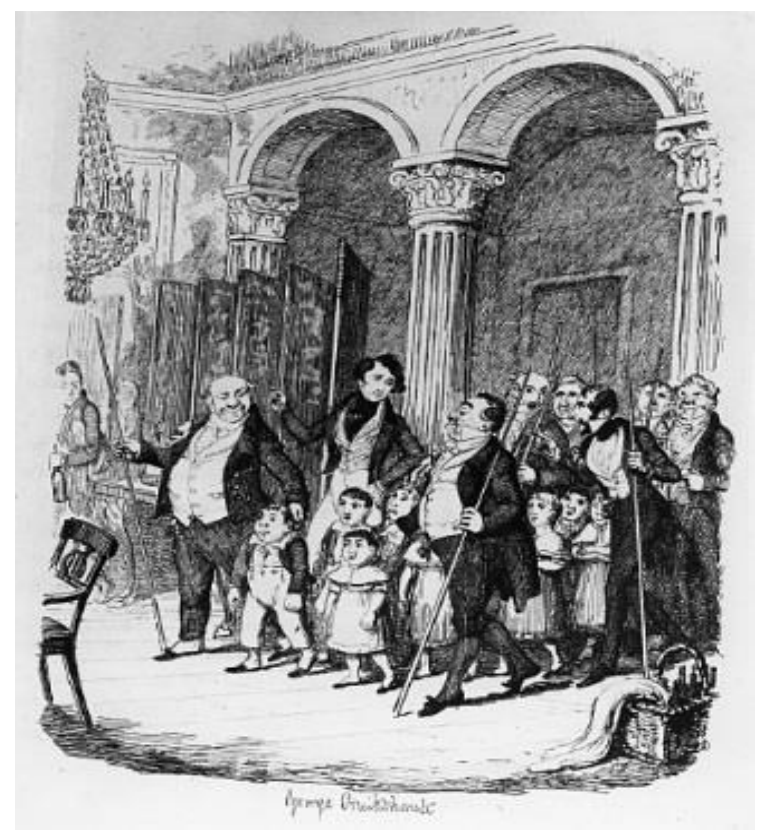

Figure 3 G. Cruikshank, "Public Dinner"

The Illustration shows the physical trait of the characters with the sharp nose and the tall body posture. They look in a really nice suit standing in a big landscape of a huge building. It reflected to the high social class man as the noble man. The next illustration is 'Monmouth Street' in chapter six of Sketches by Boz narrative. The Monmouth street is also depicted in the narrative as another notorious slums in London. As Dickens narrate in Skethes by Boz:

"We have hinted at the antiquity of our favourite spot. 'A Monmouth-street laced coat' was a by-word a century ago; and still we find Monmouth-street the same. Pilot great-coats with wooden buttons, have usurped the place of the ponderous laced coats with full skirts; embroidered waistcoats with large flaps, have yielded to double-breasted checks with roll-collars; and three-cornered hats of quaint appearance, have given place to the low crowns and broad brims of the coachman school; but it is the times that have changed, not Monmouthstreet. Through every alteration and every change, Monmouth-street has still remained the burial-place of the fashions; and such, to judge from all present appearances, it will remain until there are no more fashions to bury."(Dickens, 1895) 


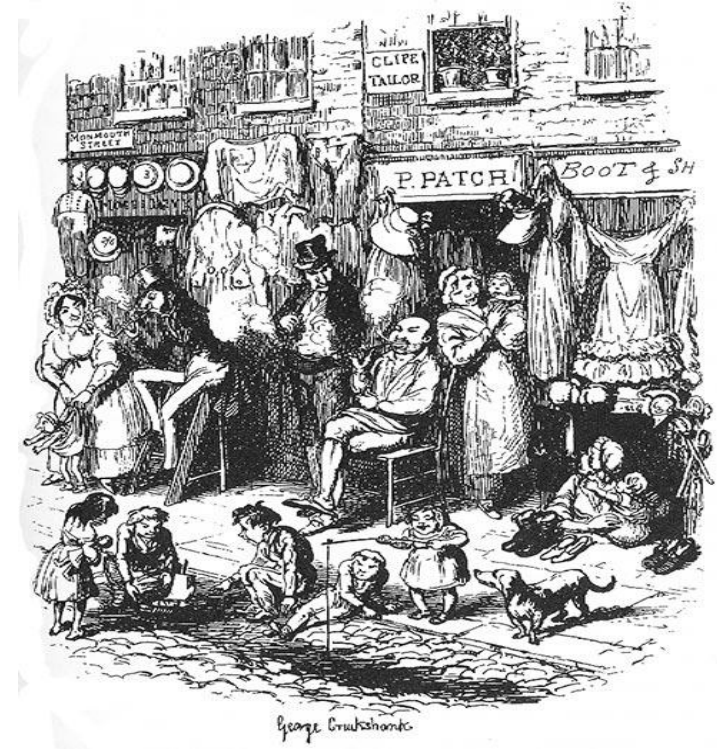

Figure 4 G. Cruikshank, "Monmouth Street

The illustration show a scene of a busy second-hand clothing shop which many characters are busy with their activity and some of them are sitting on the chair while smoking cigarettes, do sedentary activity. The appearance of the kids and the dogs give the impression of the low working social class where the children are depicted play together in a dirty ditch. There are various clothes hanging on the display. The characters are dressed in the same simple clothing reflects the condition of Victorian working class people at that time. The tones of the scenes are illustrated darker to show the gloomy atmosphere. The expression of the characters also depicted pale, the eyes are cast down. They woman tend to look down upon the object of compassion with the hands busy to hold their child. Here the illustration depicts the social class as it narrated in the book.

\section{Conclusion}

In both narration and illustration, the condition of the reality can produce the various kind of interpretation. The narration can be a really incredible means to convey the social class reality in Victorian society through the medium of language. As well as the narration also contribute in reveals the reality of social class in the society through the image. Illustration capture the images of the city space, building, costumes, and the individual characters and show the reader a clear visualization of what the narrative trying to say. Therefore, the reader can be brought to the imagination world by seeing the illustration. In conclusion, both narration and illustration highlight the social class reality in the Victorian era. The narration and the illustration cannot be separated in Dickens' Sketches by Boz since it is created to be a description of people everyday life in Victorian London. Furthermore, by examining the illustration, we can see the social status depicted from the representation of facial expression, costumes, and the setting. 


\section{References}

Browning, R. (2013). Sketches by Boz. In Dickens and the Twentieth Century. https://doi.org/10.1093/nq/175.1.15d

Cohen, J. R. (1980). Charles Dickens and his Original Illustrators. Ohio: Ohio State University Press.

Cordery, G. (2005). An Edwardian's View of Dickens and his Illustrators: Harry Furniss's "A Sketch of Boz." Greensboro, North Carolina: ELT Press.

Daniels, M. (1988). Victorian Book Illustration (N. . Wolfeboro, ed.). London: British Library.

Dickens, C. (1895). Sketches by Boz, Edwin Drood and Reprinted Pieces. London: Chapman.

Emily E. Marsh, M. D. W. (2003). A taxonomy of relationships between images and text. Journal of Documentation, Vol. 59(6), 647-672.

Forster, J. (1872). The Life of Charles Dickens: 1812-1842. London: Chapman and Hall.

Hodnett, E. (1982). Image and Text: Studies in the Illustration of English Literature. Aldershot: Scolar Press.

Indrasari, D. N., Rahman, F., \& Abbas, H. (2020). Middle Class Women Role in the 19th Century as Reflected in Bronte's Wuthering Heights. ELS Journal on Interdisciplinary Studies in Humanities, 3(2), 214-218. https://doi.org/10.34050/els-jish.v3i2.9143

Patten, R. L. (2012). Charles Dickens and "BOZ": The birth of the industrial-age author. In Charles Dickens and "Boz": The Birth of the Industrial-Age Author. https://doi.org/10.1017/CBO9781139151702

Samples, M. (2013). This world of sorrow and trouble the criminal type of Oliver Twist.

Weitzmann, K. (1970). Illustrations in Roll and Codex: A Study of the Origin and Method of Text Illustration. Princeton University Press. 